\title{
Flimsy Cocoon Mutant of Bombyx mori Larva Produces a Reduced Amount of Fibroin mRNA
}

\author{
Hideaki Maekawa*, Hiroshi Doira** and Bungo Sakaguchi** \\ *Department of Technology, National Institute of Health, Shinagawa-ku, Tokyo \\ 141, and ${ }^{* *}$ Laboratory of Sericulture, Faculty of Agriculture, Kyushu University, \\ Higashi-ku, Fukuoka 812, Japan.
}

\begin{abstract}
The proportions of fibroin mRNA synthesized in the posterior silk gland of the flimsy cocoon mutant ( $f(c)$ of Bombyx mori at days 3, 4 and 5 of the fifth instar were $1.2 \%, 0.7 \%$ and $1.8 \%$ of the labeled total RNA, respectively, whereas those in heterozygous larva $(+\mid f c)$ at the same stages were $1.6 \%, 3.2 \%$ and $8.5 \%$, respectively. The total amount of fibroin mRNA that accumulated in one larva at day 5 of $f c$ was less than $10 \mu \mathrm{g}$ and that of $+\mid f l c$ was about $110 \mu \mathrm{g}$. The intracellular distribution of the mRNA also was measured. The proportion in the nuclear fraction was $0.5 \%$ of the total labeled RNA for $f l c$ and $0.8 \%$ of that for $+\mid f l c$; in the cytoplasmic fraction the proportion was $0.2 \%$ for $f l c$ and $2.4 \%$ for $+\mid f l c$. Thus, the reduced amount of fibroin mRNA in the $f c$ mutant is considered to be due to the degradation of the synthesized mRNA rather than to a reduction in the synthesis of mRNA. It is believed that this degradation causes abnormal fibroin production. The primary action site of the $f c$ gene is not known.
\end{abstract}

In Bombyx mori some mutants have unusual cocoon formation. $N d$ mutants are characterized by low or no fibroin synthesis which produces an unusual cocoon consisting mainly of sericin, or no cocoon is formed $(4,5)$. The accumulated amount of fibroin mRNA in these mutants was 0.3 to $0.7 \%$ of the total RNA, whereas that in the wild type was $2.0 \%(8)$. The flimsy cocoon mutant which produces a thin cocoon of reduced weight is designated $f c$. The cocoon weight of homozygous larva carrying the recessive $f l c$ gene was about $30 \%$ that of the heterozygous larva $(+\mid f l c)$. The reduction in cocoon weight is due to fibroin production in $f c$ (3). Here we report that the reduced amount of fibroin in the $f l c$ mutant is caused mainly by the decreased amount of fibroin mRNA, and that a reduction in mRNA occurs in the cytoplasm.

\section{MATERIALS AND METHODS}

Materials. The strain of B. mori used was the b-60 stock maintained at the Institute of Silkworm Genetics, Faculty of Agriculture ,Kyushu University. Larvae that are homozygous $(f l c)$ and heterozygous $(+\mid f l c)$ for $f l c$ were produced by crossing $Z e+/+f l c$ females to $+f l c$ $1+f l c$ males. Gunpo $\times$ Shyugyoku was used as the wild type. The eggs of this strain were purchased from Gunze Co., Ayabe City, Kyoto, Japan. All larvae were reared at $25^{\circ} \mathrm{C}$ on mulberry leaves.

RNA extraction and the estimation of the amount of fibroin $m R N A . \quad\left[{ }^{2} \mathrm{P}\right] \mathrm{RNAs}$ were 
prepared by labeling two or three larvae for about $24 \mathrm{~h}$ with ${ }^{32} \mathrm{PO}_{4}{ }^{3-}(0.5$ to $1 \mathrm{mCi}$ per larva $)$ at days 2, 3 and 4 of the fifth instar. The posterior silk glands were dissected out in cold $1 \times \mathrm{SSC}$, and the total RNA was extracted with cold phenol after pronase digestion by a method similar to that of Suzuki and Brown (7). RNase free DNase treatment was carried out at $37^{\circ} \mathrm{C}$ for $10 \mathrm{~min}$ at $\mathrm{pH} 7.6$ in Tris- $\mathrm{HCl}$ buffer (6). The RNA in the flow through fraction from a Bio-Gel A50m column was digested with RNase $T_{1}$. Its oligonucleotides were analyzed on a DEAE-Sephadex A25 column (8). To estimate the amount of fibroin mRNA, the purity $(\%)$ of fibroin mRNA in each sample was calculated by the following equation $\mathrm{p}=100(\mathrm{~b}-\mathrm{x}) / \mathrm{b}-\mathrm{a}$, where $\mathrm{a}, \mathrm{b}$ and $\mathrm{x}$ are the percent of tetranucleotides of RNase $\mathrm{T}_{1}$ digests of; a, the purest mRNA $(1.7 \%)$; b, the artificial contaminant of 40 s ribosomal RNA $(11.6 \%)$ or heterogeneous nuclear RNA $(9.5 \%)$; and $\mathrm{x}$, the sample to be tested $(8,9)$.

Separation of nuclei and cytoplasm. Larvae were labeled for $24 \mathrm{~h}$ with ${ }^{32} \mathrm{PO}_{4}{ }^{3-}$ at day 3 of the fifth instar for $f l c$ or on day 4 of the same instar for the wild type. The method of the separation was as described by Suzuki and Giza (9). Although $98 \%$ of the total DNA was recovered in the nuclear fraction, 70 to $80 \%$ of the total RNA was found in the cytoplasmic fraction (see Table 2). The RNA extraction from each fraction and the estimation of the amount of fibroin mRNA were carried out as described above.

\section{RESULTS AND DISCUSSION}

Synthesis of fibroin $m R N A$ at the fifth instar. In the $f l c$ mutant the activity producing fibroin decreases after day 3 of the fifth instar, as shown by a low incorporation of $\left[{ }^{14} \mathrm{C}\right]$ glycine in the posterior silk gland and by reduced amounts of gelatinous silk protein stored in the lumen $(1,2)$. To determine the molecular basis of this reduction in fibroin production in $f l c$, we have analized the RNA in the $f c$ larva.

The amount of bulk RNA in the posterior silk gland of $f l c$ during the fifth instar was $80 \%$ that of $+\mid f l c$ (Table 1 ); that is consistent with the observation by Adachi and Chikushi (1). Next we determined the amount of fibroin mRNA that was synthesized and accumulated in the posterior silk gland of $+\mid f l c$ or $f l c$ at days 3,4 and 5. As shown by the brackets in Fig. 1a and $\mathrm{c}$ and in Fig. 2a and c, fibroin mRNA

TABLE 1. THE SYNTHESIS AND ACCUMULATION OF RNAS IN A PAIR OF POSTERIOR SILK GLANDS OF Bombyx mori, FLIMSY COCOON MUTANT

\begin{tabular}{|c|c|c|c|c|c|c|}
\hline \multirow[b]{2}{*}{ Genotype } & \multirow[b]{2}{*}{ Stages } & \multirow[b]{2}{*}{$\begin{array}{l}\text { Bulk RNA } \\
\qquad(\mu \mathrm{g})\end{array}$} & & \multicolumn{2}{|c|}{ Fibroin mRNA } \\
\hline & & & $\begin{array}{l}\text { Weight } \\
(\mu \mathrm{g})\end{array}$ & $\begin{array}{c}{\left[{ }^{32} \mathrm{P}\right]-\mathrm{cts} / \mathrm{min}} \\
\left(\begin{array}{c}\% \text { of total } \\
\text { labeled RNA }\end{array}\right)\end{array}$ & $\begin{array}{c}\text { Weight } \\
\left(\begin{array}{c}\% \text { of bulk } \\
\text { RNA }\end{array}\right)\end{array}$ & $\begin{array}{c}{\left[{ }^{32} \mathrm{P}\right]-\mathrm{cts} / \mathrm{min}} \\
\left(\begin{array}{c}\% \text { of total } \\
\text { labeled RNA }\end{array}\right)\end{array}$ \\
\hline \multirow[t]{4}{*}{$+\mid f l c$} & Fifth instar & & & & & \\
\hline & day 3 & 1900 & 1600 & 38 & - & 1.6 \\
\hline & day 4 & 2600 & 2200 & 81 & 2.2 & 3.2 \\
\hline & day 5 & 3400 & 2800 & 62 & 3.3 & 8.5 \\
\hline \multirow[t]{4}{*}{$f l c \mid f l c$} & Fifth instar & & & & & \\
\hline & day 3 & 1500 & 1300 & 84 & - & 1.2 \\
\hline & day $4 *$ & 2000 & - & 71 & - & 0.7 \\
\hline & day 5 & 2400 & 2000 & 54 & $<0.4$ & 1.8 \\
\hline
\end{tabular}

* Obtained from data from the nuclear isolation experiment.

- Not determined. 

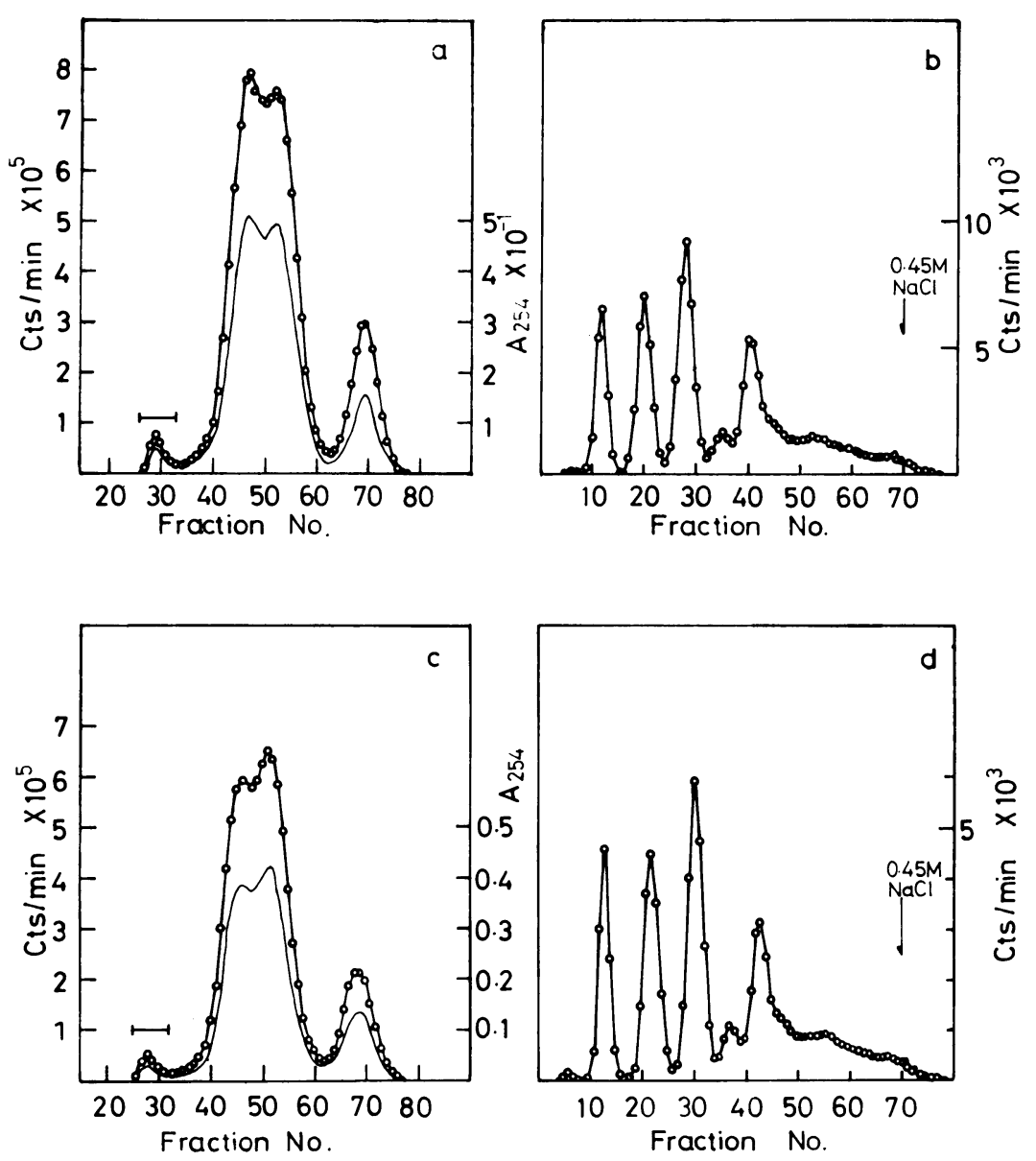

Fig. 1. Bio-Gel fractionation and RNase $T_{1}$ fingerprints. [ $\left.{ }^{32} \mathrm{P}\right] \mathrm{RNA}$ labeled for $24 \mathrm{~h}$ at day 2 of the fifth instar was applied to a Bio-Gel A50m column $(2.6 \times 58 \mathrm{~cm})$. The fractions shown in brackets were pooled, then digested by RNase $T_{1}$ and applied to a DEAE-Sephadex A25 column $(1 \times 10 \mathrm{~cm})$. Oligonucleotides were eluted with a linear gradient of 0.1 to $0.45 \mathrm{M} \mathrm{NaCl}$ in the presence of $7 \mathrm{M}$ urea. Bio-Gel fractionation, a, + $\mid f l c$; c, $f l c$. Fingerprints, b, $+\mid f l c ; \mathrm{d}, f l c-\mathrm{O}-\mathrm{cts} / \mathrm{min} ;-\mathrm{A}_{254}$.

was eluted in the flow through fraction from the Bio-Gel column (6). To estimate the amount of mRNA in the RNA samples, we pooled the RNA in the flow through fraction and digested it with RNase $T_{1}$; and this digest was applied to a DEAESephadex column (Fig. 1b and d; Fig. 2b and d). The purity of the mRNA in the flow through fraction was estimated to be about $70 \%$ in both $+\mid f l c$ and $f l c$ at the day 3 stage (Fig. $1 \mathrm{~b}$ and d). There was no significant difference between the RNAs of $+\mid f c$ and $f l c$ larvae at the day 3 stage in the column profiles from the Bio-Gel and DEAESephadex fractionations (Fig. 1). The proportion of mRNA synthesized was $1.6 \%$ and $1.2 \%$ of the labeled RNA of $+\mid f l c$ and $f l c$, respectively (Table 1 ).

However, at days 4 and 5 there was a clear distinction in the column chromatography profiles of $+\mid f l c$ and $f l c$ (Fig. 2). The purity of fibroin mRNA in the flow 

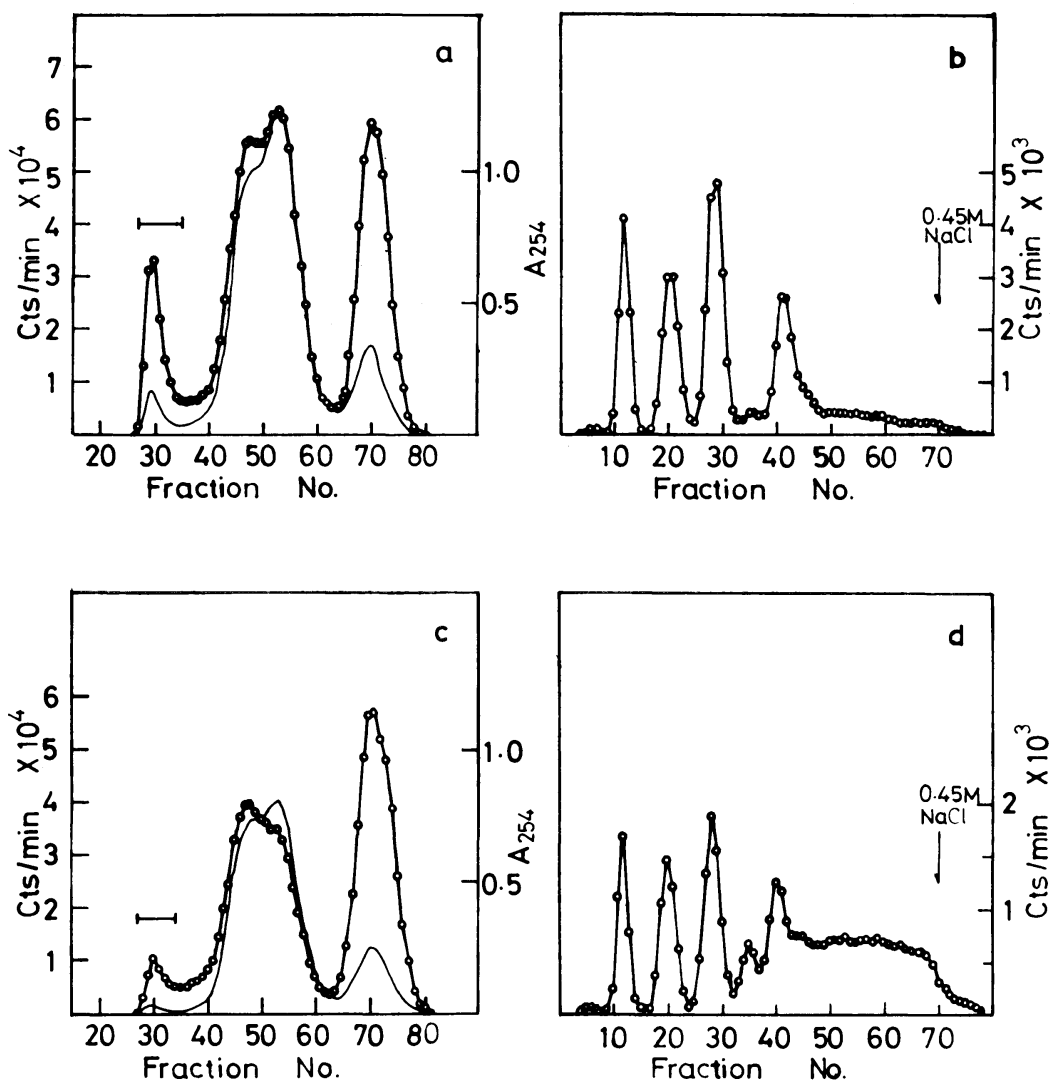

Fig. 2. Bio-Gel fractionation and $R$ Nase $T_{1}$ fingerprints. The procedure was the same as that described in Fig. 1 except that [ $\left.{ }^{32} \mathrm{P}\right] \mathrm{RNA}$ was labeled for $24 \mathrm{~h}$ at day 4 of the fifth instar. Bio-Gel fractionation, a, $+\mid f l c ; \mathrm{c}, f l c$. Fingerprints, $\mathrm{b},+\mid f l c ; \mathrm{d}, f l c-\bigcirc-, \mathrm{cts} / \mathrm{min} ;-\mathrm{C}_{254}$.

through fraction from the Bio-Gel column was $42 \%$ in day 5 larva of $f l c$ and $88 \%$ in $+\mid f l c$. The proportions of mRNA in $+\mid f l c$ at days 4 and 5 were $3.2 \%$ and $8.5 \%$ of total labeled RNA, respectively, and $2.2 \%$ and $3.3 \%$ of the bulk RNA that accumulated (Table 1). These proportions are similar to those for the wild type at comparable stages (8). The mRNA proportion in the $f l c$ larva was estimated as $0.7 \%$ and $1.8 \%$ of the labeled total RNA at days 4 and 5, respectively.

The amount of fibroin mRNA accumulated in one $f l c$ larva was less than $10 \mu \mathrm{g}$, as calculated from the value of less than $0.4 \%$ of bulk RNA at day 5 (Table 1 ). This was less than $1 / 10$ the amount for $+/ f l c$ in which about $110 \mu \mathrm{g}$ of mRNA accumulated. We thus infered that such a reduced amount of fibroin mRNA cannot support normal fibroin production.

To check the unlikely possibility that the reduction of fibroin mRNA took place during the RNA extraction procedure we carried out the following experiment. Labeled fibroin mRNA prepared from the wild type was coextracted with the total RNA of the posterior silk gland of the day $5 \mathrm{flc}$ in which the amount of fibroin mRNA is reduced. The labeled fibroin mRNA was recovered mostly in the flow through 


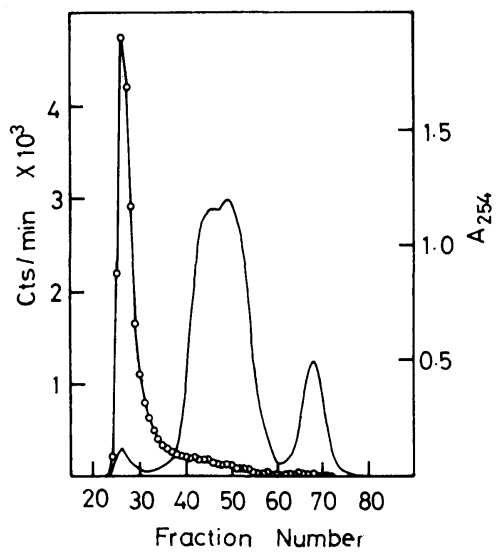

Fig. 3. Bio-Gel fractionation of re-extracted fibroin mRNA. [ $\left.{ }^{32} \mathrm{P}\right]$-fibroin mRNA was prepared from the wild type. The mRNA was homogenized with the posterior silk gland of day 5 of the fifth instar of $f c$, then the total RNA was coextracted. The RNA mixture was applied to a Bio-Gel column $(2.6 \times 58 \mathrm{~cm})$. - $\bigcirc-$, $\mathrm{cts} / \mathrm{min}$ of [32P]-fibroin mRNA; —, $\mathrm{A}_{254}$.

fraction of the Bio-Gel column (Fig. 3). This is evidence that the reduction does occur in vivo, but not during the RNA extraction procedure.

The lack of fibroin $m R N A$ in the cytoplasm of flc. The localization of fibroin mRNA in the nuclei and cytoplasm was analyzed by nuclear isolation (9). A successful separation of the nuclei and cytoplasm was made as shown in Table 2. The [32P]RNA extracted from each fraction was applied to a Bio-Gel column, then after the flow through fraction had been digested with RNase $T_{1}$, the digest was applied to a DEAESephadex column (data not shown). In the wild type preparation $80 \%$ of the bulk RNA was found in the cytoplasmic fraction, and $75 \%$ of the fibroin mRNA also was recovered there. In contrast, in $f l c$ only $30 \%$ of the fibroin mRNA was recovered in the cytoplasmic fraction, but $70 \%$ of the bulk RNA was found there (Table 2). The purity of the mRNA was $40 \%$ and $70 \%$ for $f l c$, and $57 \%$ and $80 \%$ for the wild type in the nuclear and cytoplasmic fractions, respectively. There was little difference in the localization of the bulk RNA and the purity of the mRNA in each fraction between the wild type and $f l c$.

We believe that $+\mid f l c$ is indistinguishable from the wild type because $f l c$ is a recessive gene (3). Thus we estimated that the proportion of mRNA in the nuclear fraction of $+\mid f l c$ at day 4 , was $0.80 \%(3.2 \% \times 25 / 100$; see Tables 1 and 2$)$ of the total labeled

TABLE 2. DistribUtion OF NUCLEIC ACIDS IN THE CYTOPLASMIC AND NUCLEAR FRACTIONS OF POSTERIOR SILK GLANDS OF Bombyx mori, THE WILD TYPE AND THE FLIMSY COCOON MUTANT*

\begin{tabular}{|c|c|c|c|c|c|c|c|c|}
\hline & & $\begin{array}{l}\mathrm{D} \\
(\%)\end{array}$ & $\begin{array}{l}\mathrm{NA} \\
(\mu \mathrm{g})\end{array}$ & $\begin{array}{r}\mathrm{R} \\
(\%)\end{array}$ & $\begin{array}{l}\mathrm{NA} \\
(\mu \mathrm{g})\end{array}$ & $\begin{array}{c}\text { [32P]-Bulk } \\
\text { RNA } \\
(\%)\end{array}$ & $\begin{array}{c}\left.{ }^{32} \mathrm{P}\right]-\mathrm{Ribosomal} \\
\text { RNA } \\
(\%)\end{array}$ & $\begin{array}{c}\left.{ }^{32} \mathrm{P}\right]-F i b r o i n \\
\text { mRNA } \\
(\%)\end{array}$ \\
\hline \multirow{2}{*}{$\begin{array}{l}\text { Nuclear } \\
\text { fraction }\end{array}$} & wild & 98 & 193 & 19 & 770 & 21 & 22 & 25 \\
\hline & $f l c$ & 99 & 147 & 29 & 529 & 32 & 35 & 66 \\
\hline \multirow{2}{*}{$\begin{array}{l}\text { Cytoplasmic } \\
\text { fraction }\end{array}$} & wild & 2 & 3 & 81 & 3400 & 79 & 78 & 75 \\
\hline & $f l c$ & 1 & 1 & 71 & 1270 & 68 & 65 & 33 \\
\hline
\end{tabular}

* The contents of DNA and RNA were measured by the Diphenylamine and Orcinol reactions, respectively. Values of the [ $\left.{ }^{32} \mathrm{P}\right] \mathrm{RNAs}$ were estimated from Bio-Gel fractionation and the RNase $T_{1}$ fingerprint analysis of the RNA samples extracted from each fraction. 
RNA. For $f l c$ it was about $0.46 \%(0.7 \% \times 66 / 100)$ in the nuclear fraction. This $0.46 \%$ value corresponds to $58 \%$ of the fibroin mRNA found in the nuclear fraction of $+\mid f l c$. Since the synthetic amount of fibroin mRNA in $f c$ larva at day 3 was $75 \%$ that of $+\mid f l c$ (see Table 1), the proportion of mRNA normally synthesized in the nuclear fraction at day 4 of $f l c$ was estimated as $0.60 \%(0.80 \% \times 75 / 100)$. Thus $77 \%$ of the estimated value was found in the nuclear fraction of $f c$ at day 4 . Therefore the reduced accumulation of fibroin mRNA in the $f l c$ mutant must be due to the degradation of synthesized mRNA rather than to a reduction in the synthesis of mRNA.

Earlier we suggested that secretion of fibroin to the lumen in the $f l c$ mutant was inhibited because we observed the accumulation of numerous secretary granules in the apical region (2). Because we don't know whether the reduced amount of fibroin mRNA is caused by the inhibition of the fibroin secretion, we cannot say that the $f l c$ gene regulates the secretion of fibroin and/or the amount of fibroin mRNA after day 4 of the fifth instar. However, we could conclude that the total amount of fibroin mRNA that accumulated in the $f c$ mutant by day 5 was too little to produce a normal amount of fibroin.

Acknowledgement. We thank Dr. Y. Suzuki for his critical readings of the manuscript and Drs. M. Katsuki, M. Sakakibara, H. Akai and T. Komai for their valuable advice and discussions. We also thank Miss. N. Saishu for her technical assistance, and Miss H. Suzuki and Mrs. K. Ohkubo for typing the manuscript. This study was partly aided by a Ministry of Education Grant.

\section{REFERENCES}

1. AdACHI, N. and H. CHIKUSHI. Bio-histochemical analysis of gene action in flimsy cocoon mutant of Bombyx mori. Sci. Bull. Fac. Agr. Kyushu Univ. 31, 159-173, 1977 (in Japanese with English summary)

2. AdAchi-Yamashita, N., B. SAKaguchi and H. Chikushi. Fibroin secretion in the posterior silk gland cells of a flimsy cocoon mutant of Bombyx mori. Cell Struct. and Funct. 5, 105-108, 1980

3. Dorra, H. Genetical studies of flimsy cocoon of Bombyx mori. J. Sericult. Sci. Japan 42, 425435, 1973

4. Machida, Y. Studies on the silk glands of silkworms, Bombyx mori L. II. The singluarity of the silk glands in hereditary trait, naked pupa $(N d)$, in the silkworm (1). Fukuoka Women's Junior College Studies, 3, 1-21, 1970 (in Japanese with English summary)

5. Machida, Y. Studies on the silk glands of silkworms, Bombyx mori L. II. The singularity of the silk glands in hereditary trait, naked pupa $(N d)$, in the silkworm (2). Fukuoka Women's Junior College Studies, 10, 39-44, 1972 (in Japanese with English summary)

6. Maekawa, H. and Y. Suzuki. Repeated turn-off and turn-on of the fibroin gene transcription during silk gland development of Bombyx mori. Develop. Biol. (in press)

7. Suzuki, Y. and D. D. Brown. Isolation and Identification of the messenger RNA for silk fibroin from Bombyx mori. J. Mol. Biol. 63, 409-429, 1972

8. Suzuki, Y. and E. Suzukr. Quantitative measurements of fibroin messenger RNA synthesis in the posterior silk gland of normal and mutant Bombyx mori. J. Mol. Biol. 88, 393-407, 1974

9. SuzuKi, Y. and P. E. Giza. Accentuated expression of silk fibroin genes in vivo and in vitro. J. Mol. Biol. 107, 183-206, 1976 